\title{
Comparison of Decomposition of the Stigma of Hen's Ovarian Follicle in Spontaneous and Proteolytic Enzyme-Induced Ovulation
}

\author{
Yukinori Yoshimura and Shunsaku FJII \\ Department of Animal Science, Faculty of Applied Biological Science, \\ Hiroshima University, Fukuyama
}

Ovulation in hens is known to be induced by the rupture of the stigma of the ovarian follicle. The exact mechanism of the follicular rupture, however, is still a subject of conflict, although various hypotheses have been proposed, such as the theory of muscular constriction $^{11}$, vascular ischemia of the follicular wall ${ }^{2)}$ or the intrafollicular pressure ${ }^{3)}$. Recently, NAKajo et $a l^{4}$. and Dukelow $e t a l^{51}$. reported that the intra- or extra-follicular application of proteolytic enzymes caused the rupture of the follicle in situ. Hence, they considered that these enzymes might play a role in the follicular rupture. No substantial evidence, however, has yet been given supporting for the participation of proteolytic enzymes in the morphological change of the stigma tissue.

In our previous study ${ }^{6}$, we observed remarkable structural changes that had occurred in the stratum granulosum and the theca interna of the stigma just before the time of ovulation. The present study was performed to examine the participation of proteolytic enzymes in the process of follicular rupture by comparing structural changes in the stigma. between spontaneous and enzyme-induced rupture.

\section{Materials and Methods}

The largest ovarian follicles at different stages before ovulation were collected from regularly laying White Leghorn hens by laparotomy under anesthesia with sodium pentobarbital. The developmental stages of these follicles were estimated by the time of the previous oviposition, since ovulation is known to occur in hens about 30 minutes after oviposition ${ }^{7}$. The following follicles were examined for specified purpose : 3 follicles about 12 hours before ovulation as the specimens for normal structure of the stigma at that time, 3 follicles a few minutes before expected rupture for investigation of spontaneous rupture, and 4 follicles about 24 hours before ovulation for an experiment on enzymeinduced rupture.

The experiment on enzyme-induced rupture was carried out by the method of Nakajo. et $a l^{4}$. Two enzymes, trypsin and crude collagenase (Sigma Co.), were used. They had been proved to be effective for inducing rupture ${ }^{5)}$. Small pieces of filter paper (0.6 $\left.\mathrm{mm}^{2}\right)$ which had been soaked with $0.4 \mathrm{ml}$ of enzyme solution $(1 \mathrm{mg} / \mathrm{m} l)$ adjusted to $\mathrm{pH}$ 7.4 with Tris- $\mathrm{HCl}$ were placed on the stigma of the excised follicles. The follicles were kept in a jar containing $0.9 \% \mathrm{NaCl}$ solution for moistening and incubated at $40^{\circ} \mathrm{C}$ for 45 minutes. A prolonged incubation resulted in wide-spread dissolution of follicular 
membrane.

The follicles for reference were prefixed uniformly in a $2.5 \%$ glutaraldehyde solution ( $\mathrm{pH}$ 7.4) for 30 minutes. Then small pieces of the follicular wall including the stigma were cut off, and the stratum granulosum and the theca interna were removed carefully from the follicular wall by using a needle. The rest of the wall were refixed in the same fixative for 24 hours. After the fixation, paraffin sections were prepared routinely from one half of the small pieces and stained with hematoxylin and eosin or with azan. The other half was prepared for scanning electron microscopy by conventional method. Observations were made mainly by the scanning electron microscope.

\section{Findings}

In this paper descriptions were restricted to observations on the superficial epithelium and the theca externa of the follicular wall, since the observations on remaining layers had already been described previously ${ }^{6}$. The wall of the mature follicle was composed principally of five layers; they are, from inside to outside, the stratum granulosum, theca interna, theca externa, loose connective tissue layer, and superficial epithelium.

In the mature follicle, the wall of the stigma was constituted mainly by the theca externa, comprising the greater part of its thickness. Examined microscopically, the outermost superficial epithelium was a single layer of low cuboidal epithelial cells with flattened nuclei. The underlying theca externa was composed of dense collagenous connective tissue and contained a small number of fibroblasts. Under scanning electron microscopy, the epithelial cells appeared somewhat flat and squamous, and were connected with one another by cytoplasmic processes (Fig. 1). The theca externa was formed by sheet-like bundles of collagenous fibers that were arranged in layers, and that ran parallel to the outer surface. These collagen bundles were so vague in appearance that any fiber was hardly distinguishable (Figs. 2 and 3). This appearance of the bundles was probably due to cementing between the fibers with interfibrillar ground substance. A few fibroblasts were closely packed among collagen bundles (Fig. 3).

In the follicles harvested a few minutes before ovulation, the epithelial cells were distorted remarkably in the area of the stigma, but the adjacent cells were normal in shape. They had became elongated and fusiformed, extending in a transversal direction along the long axis of the stigma. Most of them had been detached from the wall, and the underlying theca externa exposed (Fig. 4). This distortion of epithelial cells must have been induced simply by the expansion of the stigma wall as the time of rupture approached, since there was no obvious lytic damage to these cells. The exposed theca externa was extensively degraded, with its original structure loosened. Collagen bundles in the theca externa had all been dissociated into fibers or fibrils and a sparse network of fibers appeared (Fig. 5). Their dissociation is considered to have resulted from the dissolution of interfibrillar matrix by some enzymic action. Thus, a most striking difference between mature follicles and prerupture follicles was the dissociation of dense collagen bundles in the theca externa of the stigma.

When follicles were treated with proteolytic enzymes, their walls were actually 
destroyed. The stigma wall exposed to the action of enzymes was engraved into ulcertive depressions (Fig. 6). In the injured area, epithelial cells were disintegrated completely, and only fragements of their nuclei scattered. Rather noticeable changes occurred in dense collagen bundles of the theca externa was the formation of an extensive sparse network (Figs. 7 and 8). The appearance of this network suggested that some fibers might have been dissolved out. In contrast, collagen bundles remained intact in that region without enzymic infiltration. The enzyme-induced structural changes of the follicle were essentially the same, regardless of the enzyme used, trypsin or crude collagenase. The changes were apparently brought about by the lysis of the interfibrillar matrix or fibers themselves of collagen bundles.

\section{Discussion}

The ovulatory process in hen's ovary ends ultimately in the destruction of the stigma tissue which is made mainly of thick and dense collagenous connective tissue. The highly specialized structure of the stigma tissue was described in our earlier paper ${ }^{8)}$. In the ovulation of mammals, ESPEY et $a l^{9}$. reported that follicular rupture might be induced artificially by the intrafollicular application of such proteolytic enzymes as nagarase, pronase, and trypsin. They also noticed that morphological changes in enzyme-induced rupture were similar to those in spontaneous rupture. In the follicles of various mammals ${ }^{10-12)}$, the collagenous connective tissue of the thecal layer was decomposed when ovulation approached. Furthermore, some biochemical assays of the follicular tissue ${ }^{18,14)}$ have showed that there is a rapid fall in collagenolytic activity as ovulation approaches. On the basis of these deta, ESPEY ${ }^{15)}$ sugested that proteolytic enzymes might play a role in the ovulatory process.

In the study on ovulation of the hen, NaKajo et $a l^{4}$. performed similar experiments on follicles of the hen as EsPEY $e t a l^{9}$. reported. They postulated that rupture might be induced in the follicles in the same manner as in mammalian follicles. DukElow et $a l^{5}$. examined enzyme-induced rupture quite precisely, and reported that the follicular rupture was induced effectively by pronase, trypsin, and chymotrypsin, and less effectively by $\beta$ amylase and hyaluronidase. These findings suggest that proteolytic enzymes may be concerned in the rupture of chicken follicles.

In the present study, the induced rupture of the stigma tissue was characterized by the dissociation of collagen bundles. As described in spontaneous rupture, the collagen bundles of the theca externa were completely dissociated into fibers or fibrils. The same morphological changes appeared in the rupture induced by trypsin or crude collagenase. The changes might be attributed to the hydrolytic action of these enzymes. From these results, it was concluded that in the normal ovulation process certain proteolytic enzyme might act in such a manner as to make the stigma tissue distorted prior to rupture of this tissue.

As for the source of such an enzyme, EsPEY ${ }^{16 /}$ and OKamura et al ${ }^{12}$. presumed that it might be one of lysosomal enzymes contained in the fibroblasts of the follicular wall, since fibroblasts became multivesicular in the peripheral cytoplasm as ovulation drew near. In the present study, such morphological changes in the fibroblasts were not 

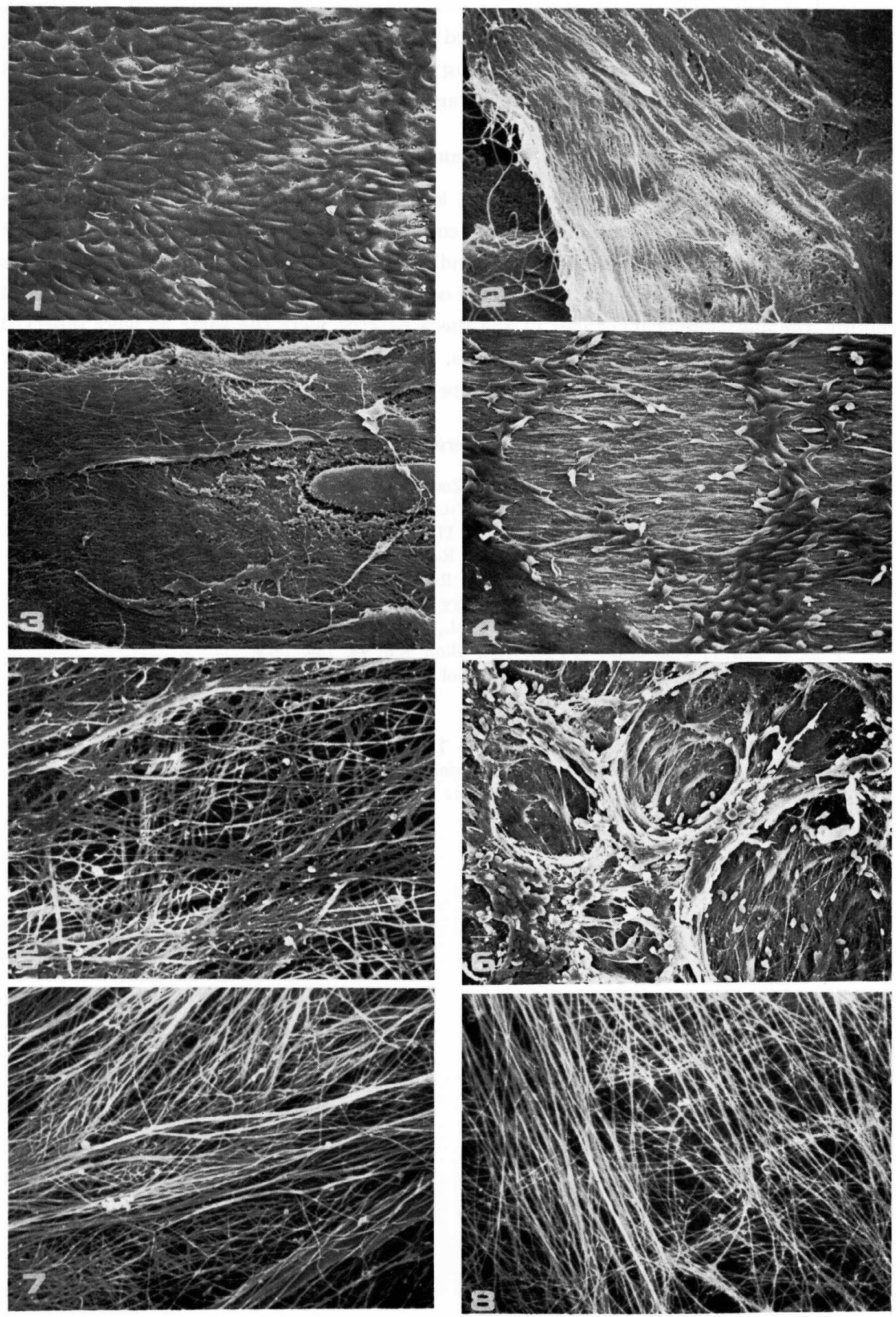

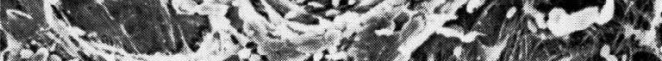

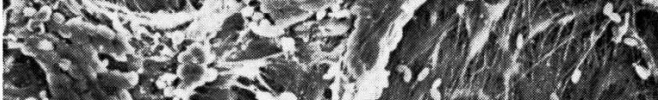

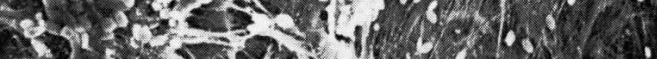
E.
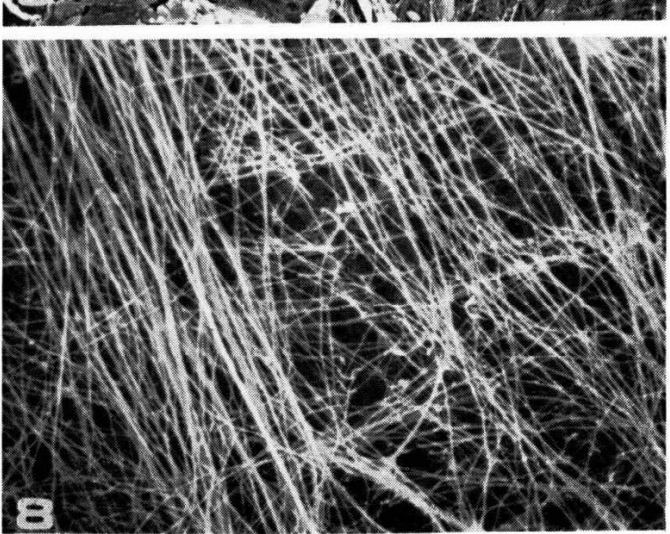
observed in the chicken follicle by the scanning electron microscopy. In conclusion, ovulation in hens may possibly be influenced by two factors; they are 1) increase in intrafollicular pressure and 2) the preceding reduction of tensile strength of the stigma induced by the enzymic dissociation of collagen bundles.

\section{Summary}

Structural changes of the stigma tissue in the ovulatory process of hens were examined in two types of rupture, spontaneous and proteolytic enzyme-induced. In the spontaneous rupture, the dense collagen bundles of the theca externa of the stigma were dissociated into fibers or fibrils prior to the occurrence of rupture. In the enzyme-induced rupture, the morphological changes of the theca externa were the same as were observed in the spontaneous one. From these results, it is suggested that enzymic dissolution of the stigma tissue may take place just before spontaneous ovulation.

\section{References}

1) Phillips, R. E. and D. C. Warren: J. Exp. Zool., 76, 117, 1937.

2) Nalbandov, A. V.: Control of Ovulation, (Villee, C. A., ed.), Pergamon Press, London, 1961.

3) Pearl, R. and M. R. Curtis: J. Exp. Zool., 17, 395, 1914.

4) Nakajo, S., A. H. Zakaria, and K. Imai: J. Reprod. Fert., 34, 235, 1973.

5) Dukelow, W. R. and T. J. Maatman: Anim. Reprod. Sci., 1, 75, 1978.

6) Yoshimura, Y. and S. Fujil: Japanese Poultry Sci., 16, 287, 1979.

7) Olsen, M. W. and B. H. Neher: J. Exp. Zool., 109, 355, 1948.

8) Fujil, S. and Y. Yoshimura: J. Fac. Appl. Biol. Sci., 18, 185, 1979.

9) Espey, L. L. and H. Lipner: Amer. J. Physiol., 208, 208, 1965.

10) EsPey, L. L.: Endocrinology, 81, 267, 1967.

11) PARR, E. L.: Biol. Reprod., 11, 483, 1974.

12) Okamura, H., A. Takenaka, Y. Yajima, and T. Nishimura: J. Reprod. Fert., 58, 153, 1980.

13) Espey, L. L. and P. Rondell: Amer. J. Physiol., 214, 326, 1968.

14) Okazaki, T., H. Okamura, and T. Nishimura: Acta Obst. et Gynaec. Jap., 20, 112, 1973.

15) EsPey, L. L.: Biol. Reprod., 10, 216, 1974.

16) Espey, L. L.: Endocrinology, 88, 437, 1971. 


\title{
鷄の自然排卵亡蛋白分解醳素誘起排卵における \\ 卵胞スチグマ組織の構造的変化の比較
}

\author{
吉 村 幸 則・藤 井 俊 策 \\ 広島大学生物生産学部, 福山市 $\bar{T} 720$
}

最近，鷄の排卵恃の卵胞スチグマ破裂に蛋白分解酵素 が関与していることを示唆する報告がみられる。本研究 はこの可能性を明らかにするために, 自然排卵と蛋白分 解酵素誘起排卵時のスチグマ組織の構造的変化を比較観 察した。

破裂前の成熟卵胞のスチグマ部は, 卵胞壁の厚さの大 部分を外卵胞膜層によって占められていた。外卵胞膜層 は強固な線維性結合組織であって, 主として薄板状の膠 原線維束の重層配列によって構築されていた。

排卵直前のスチグマ部は顕著な構造的変化を伴ってい
た。とくに外卵胞膜の膠原線維凁は崩塤し，単線維ある いは細線維に解疎していた。いっぽう，トリプシンまた は粗製コラゲナーゼ処理によって唀起された卵胞破裂時 にも，自然排卵時における同様の外卵胞膜の噖原線維束 の崩壞が認められた。この際の膠原線維束の破壤は, 醋 素作用によって線維間結合物質の融解あるいは線維自体 が消化されたたらと考えられた。以上のように，汿者の スチグマ組織の構造的变化は全く類似していたことか ら, 卵胞破裂には蛋白分解酵素が関与している可能性が 推察された。（家离会誌，18，60〜65, 1981） 